\title{
Spin-off and clustering: a return to the Marshallian district
}

\author{
Lucia Cusmano, Andrea Morrison and Enrico Pandolfo ${ }^{\star}$
}

\begin{abstract}
The origin and growth of industry clusters have attracted the attention of scholars and policy makers since the early era of industrialisation. The seminal work by Alfred Marshall has represented the foundation for a rich strand of literature, whose late expansion and refinement were inspired by the experiences of localised development in emerging regions. This is the case of Italian industrial districts, which have emerged as a territorial model of industrial agglomeration, decentralised production and flexible specialisation. Recently, the traditional explananda of the emergence of clusters have been reconsidered. The evidence about the growth of clusters in areas that did not have obvious natural advantages, or the first comers' benefits of early agglomeration economies, has inspired a different conceptualisation, which draws consistently from the evolutionary perspective on industrial dynamics. Klepper shows that more successful firms have higher spin-off rates and their spin-offs tend to outperform competitors. Organisational reproduction and heredity are thus identified as the primary forces underlying clustering. The present paper investigates the emergence and evolution of an Italian industrial district, the Sassuolo tile district, one of the largest and most successful ceramic districts in the world and a paradigmatic example of an Italian Marshallian district. Overall, our findings confirm that organisational reproduction and heredity represent primary mechanisms of clustering. However our results also show that spin-offs do not perform better than non-spin-offs. It appears that, in dense industrial environments and social networks, competitive advantages can also be acquired or built through other channels.
\end{abstract}

Key words: Spin-off, Industrial cluster, Industrial dynamics, Entrepreneurship fEL classifications: D22, L26, R10

\section{Introduction}

The origin and growth of industry clusters have attracted the attention of scholars and policy makers since the early era of industrialisation, whose evolution in time

Manuscript received 29 September 2012; final version received 14 February 2014.

Address for correspondence: Andrea Morrison, URU, Section of Economic Geography, Utrecht University, Heidelberglaan 2, 3584 CS Utrecht, The Netherlands; email: a.morrison@uu.nl

* OECD Centre for Entrepreneurship SMEs and Local Development, Paris, France (LC), Utrecht University, The Netherlands and Bocconi University, Milan, Italy (AM) and Watson Group, Zurich, Switzerland (EP). We wish to thank Assopiastrelle in Sassuolo for letting us access the resources and archival data of their library. Special thanks go to the entrepreneurs and professionals interviewed in Sassuolo, who gave us their time and knowledge. Financing from the European Commission, Framework Programme 7, AEGIS (Advancing Knowledge-intensive Entrepreneurship and Innovation for Economic Growth and Social Well-being in Europe) is gratefully acknowledged. Andrea Morrison acknowledges also the financial support of NWO, Innovational Research Incentives Scheme/VIDI.

(C) The Author 2014. Published by Oxford University Press on behalf of the Cambridge Political Economy Society. All rights reserved. 
L. Cusmano et al.

has in fact been largely characterised by trends towards geographical concentration and territorial imbalances. The seminal work by Alfred Marshall has represented the foundation for a rich strand of literature, whose late expansion and refinement were inspired by the experiences of localised development in emerging regions, the growth of technology clusters or the 'diffused' industrialisation taking place in once peripheral areas. This is the case of Italian industrial districts, which, since the second half of the 1970s, have emerged as a territorial model of industrial agglomeration, decentralised production and flexible specialisation (Piore and Sabel, 1984). The emergence and growth of Italian districts have been often related to Marshallian externalities, especially favoured by conducive local institutions, cultural commonalities, shared values and trustful cooperative relationships among local players (Becattini, 1990).

In recent years, across different strands of economic literature, from industrial dynamics to economic geography, increasing attention has been placed on the dynamics of industrial agglomerations and established paradigms have been questioned (Boschma and Fornhal, 2011; Menzel and Fornhal, 2010; Iammarino and McCann, 2006). As varied experiences have come under study, the traditional explananda of the emergence and performance of clusters have been reconsidered. In particular, Marshall's conjectures about clustering forces have been tested in the light of the historical evolution of prominent industry clusters, mainly in the USA (Klepper, 2001). To explain the growth of clusters in areas that did not have obvious natural advantages, or the first comers' benefits of early agglomeration economies, other theoretical arguments about clustering dynamics have been proposed, which draw consistently from the evolutionary perspective on industrial dynamics, alternative or complementary to the traditional Marshallian narrative. The seminal works by Klepper (2001, 2009, 2010) and Klepper and Sleeper (2005) elaborate the evolutionary concept of 'heredity' to explain the role that spin-offs have in the growth and performance of clusters. Spin-offs are entrants founded by employees of firms in the same industry, which inherit knowledge and competencies from their parent firms. This parental heritage distinguishes them from other players and importantly affects their performance and likelihood to generate themselves other spin-offs. Klepper and colleagues show that, in prominent US clusters, more successful firms have higher spin-off rates and their spin-offs tend to outperform competitors. Organisational reproduction and heredity are thus identified as the primary forces underlying clustering. However, this important finding does not necessarily rule out the importance of traditional agglomeration economies, which might still play a significant role during different stages of the cluster life cycle (Boschma and Wenting, 2007), or other possible factors that contribute to the cluster emergence, such as initial conditions or capabilities generated in the local milieu (Belussi and Sedita, 2009).

The present paper intends to contribute to the above literature debate by providing fresh evidence on the evolution of a typical Italian industrial district and its main driving forces. We investigate the emergence and evolution of the Sassuolo tile district, one of the largest and most successful ceramic districts in the world and a paradigmatic example of an Italian Marshallian district. Our empirical analysis draws on an original dataset of the founders of firms belonging to the Italian tile industry, which allows us to reconstruct the evolution of the Sassuolo district overtime. In line with Klepper's works, we investigate the spin-off dynamics and its contribution to the process of agglomeration. We analyse the type of firms that spawned off and the characteristics of their parent company, as well as the relationship between the performance of parents and their 
spin-offs. By comparing this district evidence with the main findings of the literature, we intend to assess the degree to which the typical district features impact on the entrepreneurial dynamics, i.e. whether, in the Italian case, once entry by spin-off is taken into account, a 'Marshallian district' exception can still be identified. The paper is organised as follows. Section 2 presents a literature review on the determinants of clustering. It focuses in particular on the debate about the emergence and dynamics of industrial districts in the Italian context. It then introduces the main findings from recent studies on spin-off dynamics and clustering, highlighting differences between these strands. Section 3 describes the historical background and business demographics of the tile industry in Italy, illustrating the relevance of the Sassuolo area for the entire sector. Section 4 presents the empirical analysis, commenting on data development and methodology and reporting results on spin-off fertility and location, spin-off performance and the background of the entrepreneurs. Section 5 concludes.

\section{Determinants of clustering and the industrial district case: theoretical background}

In the economic literature, the emergence of industry clusters is often related to 'Marshallian externalities' (see, e.g., David and Rosenbloom, 1990; Glaeser et al., 1992), i.e. economies of scale external to the firm but internal to a territorial system, which favour agglomeration. The Marshallian argument identifies in the reduction of production costs a powerful driver of geographical concentration (Marshall, 1920). Physical proximity favours the emergence of pecuniary externalities as firms can easily access, at lower costs, resources, specialised markets of inputs and providers. In addition to access to resources and more favourable cost conditions, industry-specific clustering makes it easier for firms and workers to match their idiosyncratic characteristics and facilitate learning via localised technology or knowledge spillovers (Krugman, 1991; Audretsch and Feldman, 1996; Klepper, 2011; Maskell and Malmberg, 1999). ${ }^{1}$ Firms learn through user-producer relationships along the value chain (Lundvall, 1992) as well as along horizontal linkages, via informal know-how trading with competitors (von Hippel, 1987). Knowledge externalities increase the stock of knowledge available to each individual firm, but as they largely consist in the dissemination of tacit knowledge, their appropriation requires some common code or background and a process of social interaction (van der Panne and van Beers, 2006).

The literature on Italian industrial districts particularly emphasises the social dimension of industry agglomeration (see, e.g., Becattini, 1979, 1990; Brusco, 1982; Piore and Sabel, 1984). In specific territorial systems, the proximity in cultural and social terms, which typically developed through an industrial trajectory rooted in local traditions, by reducing transaction costs and favouring knowledge exchange, facilitates the emergence of a model of flexible specialisation. The local firms, generally SMEs, perform highly specialised functions, which recombine through flexible mechanisms at the territorial level (Scott, 1988; Garofoli, 2002). In this context, outsourcing of activities at the local level is common and mainly driven by motivations other than costs, such as production smoothing, core-competence focus or expertise- and knowledge-searching strategies (Cusmano et al., 2010). This network-based organisation of production at

\footnotetext{
${ }^{1}$ An alternative argument, inspired by Jacobs (1969), identifies interindustry agglomeration forces ('diversification externalities'), highlighting the knowledge exchange across firms in complementary sectors.
} 
the territorial level can turn into a locus of innovation, fuelled by knowledge externalities (Camagni, 1991). Also, local learning is enhanced by labour market pooling à la Marshall and the high degree of labour mobility, which often takes the form of spinoffs, as former employees become entrepreneurs. Indeed, the entrepreneurial dynamics is a distinctive feature of industrial districts, largely propelled by subcontracting practices, which determine a fine division of labour along the supply chains. As Maillat (1995) emphasises, successful districts generate a 'fabric of new enterprises'. Belussi and Sedita (2009) illustrate the relevance of the spin-off dynamics for this fabric in the case of several successful districts in Italy. This fabric can be also interpreted as a 'natural incubator of new projects of life coming from the experiences and energies of the industrial district working class' (Becattini et al., 2009, p. xxix). The founders of these start-ups do not only invest their savings, but also the technical and managerial reputation they built over an entire career life and which is strongly rooted in a community of both human and economic relations (Becattini et al., 2009, p. xxviii). Founders are, in the great majority, workers of firms active in the same or related sectors, mostly specialised blue collar workers who built their competences on the job through learning by doing rather formal education (Brusco, 1982; Solinas, 1996).

According to the above literature, however, the entrepreneurial process is largely influenced by context-specific factors. That is, the formation of new firms, start-ups and spin-offs is importantly affected by the local social and economic milieu (Garofoli, 1994). The low barriers to entry for new firms derive not only from the relatively small scale of operation and initial investment required for the individual firm, but also from the supply of 'collective goods' at the territorial level, such as education and training, $\mathrm{R} \& \mathrm{D}$ or technical services, generally provided by local institutions. Furthermore, knowledge spillovers and the broad diffusion of information about markets (e.g. suppliers, competitors and clients) help to identify business opportunities. The capacity to take advantage of these spillovers, however, is greater for the 'potential entrepreneurs' who share the local 'industrial culture'. The high labour mobility and the rapid start-up of new enterprises are supported by family networks, other district entrepreneurs and access to financial resources at the local level (Dei Ottati, 2002). Examples of these processes can be found both in traditional manufacturing districts (see, e.g., Brusco, 1982) as well as in high-tech and science-based districts (see, e.g., Best, 2009; Patton and Kenny, 2009).

The industrial district literature offers also important insights to understand the localisation of spin-offs. In particular these start-ups tend to be located close to their mother firms (i.e. in the district area) since their emergence and development heavily relies on both human and relational capital, which are less footloose than technological and financial capital (Becattini et al., 2009, p. xxviii) and so difficult to be transferred into different economic and institutional contexts.

If the traditional literature on districts highlights the role of institutional and context-specific factors, i.e. of meso-level conditions, recent studies place the focus on the individual firm level and on how firm's strategies impact on the district evolution (see, e.g., Rullani, 1997; Lazerson and Lorenzoni, 1999; Biggiero and Sammarra, 2003; Hilliard and Jacobson, 2011; Paniccia, 1998). For example, Lazerson and Lorenzoni (1999) elaborate a micro-based view of cluster evolution in which leader firms and network-based relations constitute the main drivers of cluster dynamism. The authors underline the variety of district experiences and organisational forms in Italy and focus on the case of interfirm networks that are characterised by quasi-hierarchy, in which 
'focal' firms play the important role of funnelling new ideas and knowledge into the productive structure of the district. The generation of spin-offs is one of the key channels through which these firms can impact on the local system dynamics.

\subsection{Spin-off and clustering}

Recent empirical studies on the dynamics of spin-off in prominent industry clusters have contributed to advance alternative explananda of the clusters' growth and performance (see, e.g., Klepper and Sleeper, 2005; Klepper, 2007; Buenstorf and Klepper, 2010; Boschma and Wenting, 2007). In his studies on industrial agglomerations in the USA, such as Detroit and Silicon Valley, Klepper (2007, 2009, 2010) argues that regional culture, local institutions and agglomeration economies were not the primary sources of the clusters' emergence and consolidation. Klepper and colleagues rather contend that the process of agglomeration was driven largely by spin-offs, i.e. by employees from firms in the same industry starting their business. Moreover, they argue that the success of these clusters can be explained by and confined to the success of the spin-offs created.

This conceptualisation draws from the evolutionary concept of 'heredity' (cf. Nelson and Winter, 1982), which involves reproduction and transmission of genes to offspring (Klepper and Sleeper, 2005). The parental inheritance of spin-offs consists in knowledge, competencies and routines, which distinguish them from other firms in the industry. Furthermore, spin-offs often target new niche markets or technologies their parents are unwilling or slow to pursue, taking advantage of the information acquired at the parent firm. In other terms, the knowledge spillovers and information on markets, technologies and business opportunities described by the literature on industrial districts as meso-level externalities are even more pronounced for insiders of dynamic firms and, also for this reason, their spin-offs tend to outperform competitors. At the same time, spin-offs are not a zero-sum game, cannibalising the market of their parents. Rather, they tend to seize the opportunities overlooked by them (Klepper and Thompson, 2010). In fact, spin-off rates tend to be higher at times of acquisition or changes in the managerial structure, which can generate or accelerate contrasts with employees, inducing some of them to leave and start a new business, as observed by Klepper and Thompson (2010) in a study covering different sectors, including automobiles, lasers and semiconductors.

As Buenstorf and Klepper (2010, p. 113) notice, 'the on-the-job learning of prospective spin-off founders constitutes a knowledge spillover and could thus be seen as a specific form of localization economy operating through entrepreneurship rather than production externalities'. This latter view implies that capable entrants are more likely to be spin-offs of capable parent firms. In fact, a key finding of the empirical studies in this area is that more successful firms have higher spin-off rates and their spin-offs perform on average better than other new firms. For example, Klepper and Sleeper (2005) develop a model in which spin-offs inherit knowledge from their parents and test it with data on the laser industry's evolution in the USA. They find a significant correlation between the spin-offs' focus of activity and the lines of business of the parent firms. They also find that higher spin-off rates are associated with more successful firms. Analysing the semiconductor industry in Silicon Valley and the automobile industry in Detroit, Klepper (2010) relates the superior performance of spin-offs of leading firms to innate characteristics they possessed at the time of entry, rather than to externalities in the local cluster. 
Indeed, clustering itself is, according to these studies, an outcome of organisational reproduction and heredity, as spin-offs tend to locate close to their parent firms. As better firms reproduce at a higher rate and generate better-performing spin-offs, it is the presence of an early exemplary performer (e.g. Olds Motor Works in Detroit and Fairchild in Silicon Valley) that explains the growth of clusters (Klepper, 2010). Buenstorf and Klepper (2010) similarly show, using historical evidence on the US tyre industry, that spin-off activities from the leading firms led to concentrated entry in and around the localisation of the parent firms. This is not to deny that agglomeration economies à la Marshall also play a role. These drivers might in fact reinforce each other. Klepper (2010), however, emphasises that even when agglomeration economies are at work, enhancing the profitability and hence the probability of entry of indigenous potential entrants, the superiority of entrants' performance, which determines the growth and survival of the cluster over time, is largely restricted to spin-offs from top-performing firms. Nevertheless these latter studies remain somehow vague when it comes to the explanation of why spin-offs tend to locate close to their mother firms. In some instances they argue that founders' decision to locate in the district is due to personal reasons (they locate the firm where their family lives). Nevertheless they also do not discard typical districts explanations (Klepper, 2009), such as the presence of relational capital or social networks, which can represent important mechanisms to levy both financial and knowledge capital, or demonstration effects, which have been shown to be one of the most powerful mechanisms of firm creation in Italian industrial districts, including Sassuolo (Becattini et al., 2009; Brusco, 1982; Russo, 1985).

In line with the aims and the methodology adopted in these studies, the present paper investigates the spin-off dynamics and its contribution to the performance of firms in a well-established Italian industrial district. We analyse the performance both of the firms that spawned off and their parent company, as well as their localisation (i.e. within or outside the district). By comparing this evidence with the main findings of the literature, we intend to assess the relevance of spin-off dynamics à la Klepper and the degree to which, on the other hand, other peculiar district features impact on the entrepreneurial dynamics.

\section{The tile industrial district of Sassuolo}

\subsection{Historical background}

The tile industry developed in Sassuolo, in the Emilia-Romagna region, after World War II, although its growth is strongly rooted in artisanal traditions. The first ceramic production in Sassuolo dates back to 1743; at that time the industry was led by producers clustered in the near city of Faenza. In the post-War period, several factors contributed to the development of a production cluster in Sassuolo: a resource advantage, as clay deposits close to Sassuolo allowed for relatively low transportation costs; an institutional change, as the development of local banks, such as the Banca Popolare di Modena, facilitated access to capital, largely on the basis of long-term relationships and trust; and a regulatory change, as the area benefitted from the laws established in Italy in the 1950s to favour investments in underdeveloped regions by way of tax exemptions or tax credits (Muzzioli et al., 2006; Serri, 2008). Furthermore, boosted demand in the post-War period and important breakthroughs in the production technology, 
such as the first continuous production method and single-firing techniques, favoured the expansion of the sector (Vertova, 2004).

The first period of expansion was followed in the 1970s and early 1980 s by a more unstable development path, as growth alternated with economic crisis, such as the oilrelated one in 1974. Through the end of the 1970s and the 1980s, technological change contributed to a reorganisation of the industrial structure of the district, in particular favouring the concentration in a few large groups (Russo, 1985). A major technological breakthrough was the single-firing technique ('monocottura') that reduced the firing time from 24 hours to 55 minutes. The new method for the rapid firing of tile body and glaze was developed by a Sassuolo leading firm, Marazzi, and rapidly diffused to other firms in the area and abroad, becoming the standard method of ceramics production all over the world (Russo, 1996). This innovation led to an increase in productivity and a significant reduction in costs, which also favoured the expansion of exports by local firms to Europe and the USA. The industry shifted from labour intensity to capital intensity and the consumption of energy implied by the tile production process was significantly reduced. Most interestingly, the greater vertical integration, which followed the changes in the methods of production, also led to higher barriers to entry and marked the beginning of a process of concentration in the industry. Already in the 1980s, 12 firms accounted for $50 \%$ of the Italian production (Bentivogli and Scillitani, 2002). The concentration took place mainly through mergers and acquisitions and the formation of industrial conglomerates, facilitated by the reduced information asymmetry between market counterparts in the district (Russo, 1996).

In the 1990s another technological break changed the industry, as the 'gres porcellanato' was introduced. This is a type of ceramics that is more resistant and allows for new applications, such as in the decoration of floors. Marketing functions increased their importance and more complex commercial strategies were developed by district firms.

Since the 1990s the concentration in the district has increased significantly. The local production system has clearly evolved towards a more hierarchical structure dominated by few large conglomerates and a number of medium and large firms (Belussi, 1996; Bursi and Nardin, 2008). Moreover, along with concentration, since the 2000s a strong process of internationalisation has taken place in the form of both acquisition of foreign companies and delocalisation of production activities, which is most often driven by the largest groups in the district (Confindustria Ceramica, 2011; Rabellotti et al., 2009; Bursi and Nardin, 2008). The Italian ceramic industry accounts for $35 \%$ of world export and the Sassuolo district represents more than $80 \%$ of the Italian production. Nevertheless, increasing international competition, with China becoming the largest producer worldwide (Confindustria Ceramica, 2011), has put pressure on the competitiveness and organisational structure of the district (Bursi and Nardin, 2008; Russo, 2004).

\subsection{Business demographics}

The rate of entry into the Italian tile industry was highest in the first period of its expansion, particularly in the 1960s. In more detail, the rate of firm creation was highest between 1961 and 1976, when the population of firms reached its historical height of 509 firms (Figure 1). The later processes of exit and acquisition show up in the negative trend in the business population. The rate of exit slowed in the mid-1980s to increase later in the 1990s. In 2007, the business population had reduced to 206 firms, 


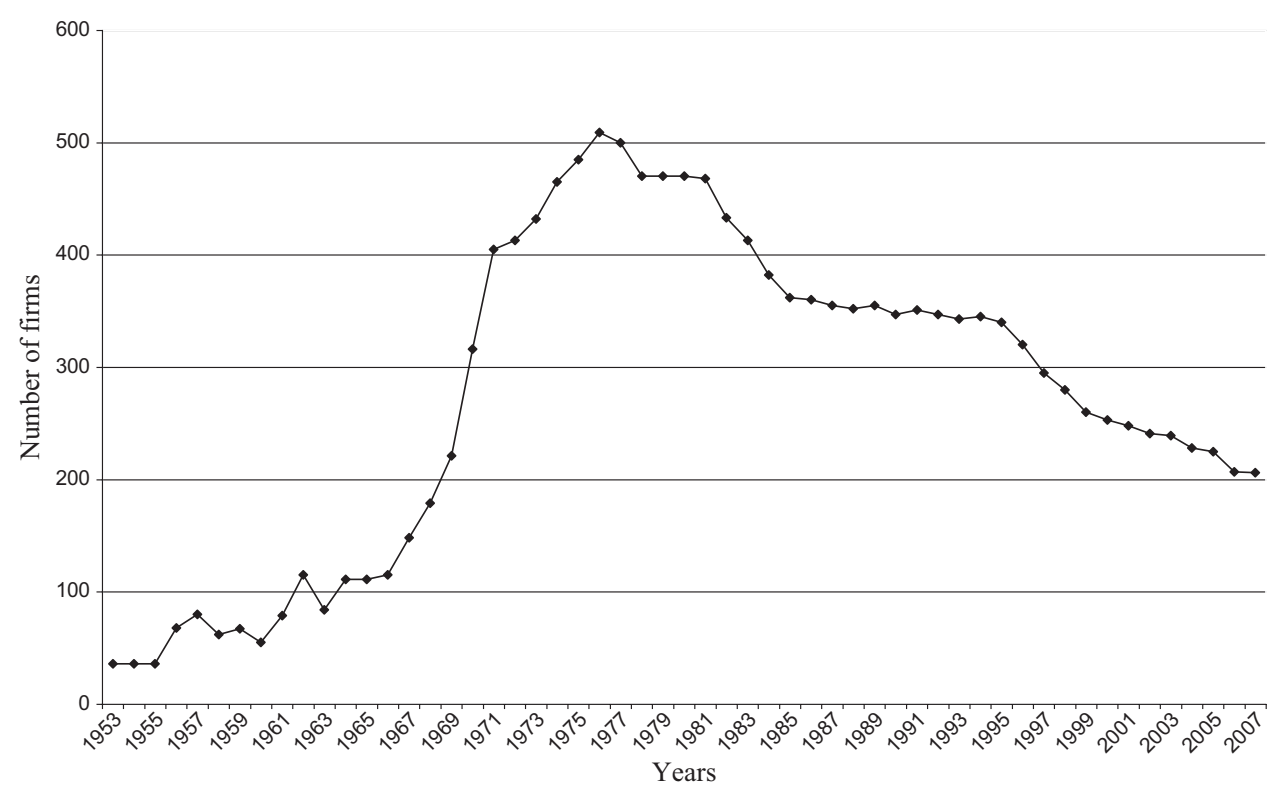

Fig. 1. Italian tile industry: number of firms, 1953-2007.

Source: Our elaboration on data from Confindustria Ceramica $(2007,2008)$.

half of which (102) were located in the provinces of Modena and Reggio Emilia, i.e. within and close to the Sassuolo area (Table 1).

These cycles in business demographics are common to other clusters across regions and sectors. For example, in the USA, Silicon Valley and Detroit experienced the greatest entry rates in the early stages of the cluster formation and were later shaped by shake out and consolidation (Klepper, 2009).

In the tile industry, these cycles also reflect into employment. The number of employees expanded during the 1960s, up to 1976, to decline afterwards following the introduction of the less labour-intensive single-firing technique. However, contrarily to the number of firms, the employment stabilised in the mid-1990s (Figure 2).

\section{Empirical analysis}

\subsection{Data and methodology}

Our analysis draws on three main sources of data. First, we extracted all companies belonging to the ceramic sector (Industrial classification NACE 23.31) from the national register of companies of the Italian Chamber of Commerce. The information available in the register includes the birth and failure dates of firms and their location (i.e. address, city, province and region). Second, we complemented this dataset with data included in the Assopiastrelle ${ }^{2}$ annual register of firms. This provides additional information on firms' revenues and number of employees. Data have been cleaned in order to exclude non-manufacturing firms, which are mainly retailers. To test for the importance of clustering effects, following Klepper (2009), we include in the analysis

\footnotetext{
2 Assopiastrelle is the national business association of firms operating in the ceramic sector. Most firms in the industry participate in Assopiastrelle.
} 
Table 1. Italian tile industry: distribution of firms by Province, 2007

\begin{tabular}{lc}
\hline Province & Percentage of tile firms \\
\hline Modena & 34 \\
Reggio Emilia & 23 \\
Rest of Italy & 43 \\
Total & 100 \\
\hline
\end{tabular}

Source: Our elaboration on data from Confindustria Ceramica $(2007,2008)$.

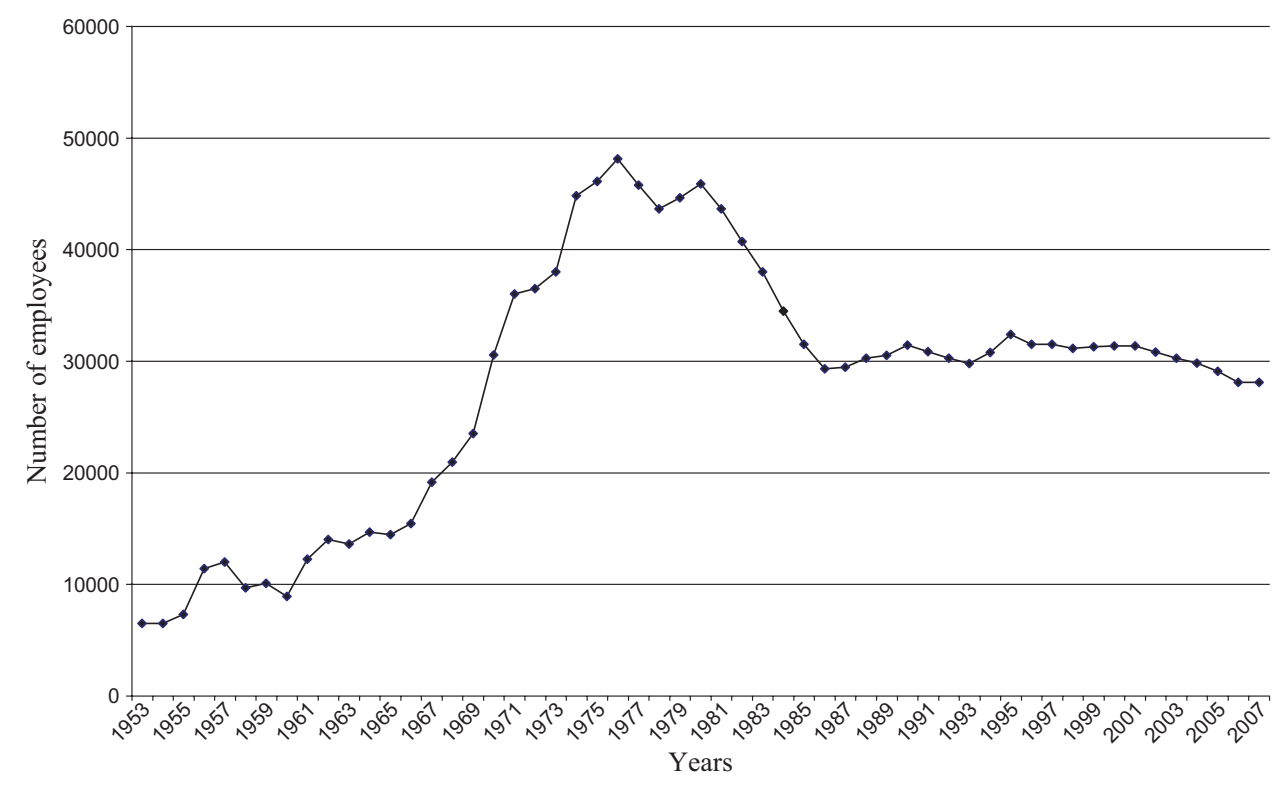

Fig. 2. Italian tile industry: number of employees, 1953-2007.

Source: Our elaboration on data from Confindustria Ceramica (2007, 2008).

firms from outside the district of interest, which are located in other Italian regions with a relevant activity in the ceramic sector. These regions are Veneto, Toscana and Campania. The period investigated ranges from 1953, when the Sassuolo district took off, to 2007. The final dataset includes 581 firms. Third, data on the background of entrepreneurs have been collected through interviews with experts, the archive of the local branch of Assopiastrelle, company web sites, sector magazines and other relevant literature on the Sassuolo tile industry. We found reliable information on the past experience of entrepreneurs for 159 firms, which represent $27 \%$ of the population. This share is comparable with those of other studies that analyse spin-offs' dynamics and industry evolution (see Boschma and Wenting, 2007; Klepper, 2007). Out of the 159 firms, 87 (55\%) were founded by entrepreneurs who had worked for or founded a company in the tile sector in Italy. These companies are tagged as 'spin-off', whereas the remaining 45\% (72 firms) are classified as 'non-spin-off'. Data on revenues were used to assess the performance of firms. However, these data are available only for the most recent decades, since 1992. 
Table 2. Sample firms by province and region

\begin{tabular}{lr}
\hline Region and province & Perce \\
\hline Modena and Reggio Emilia & 69 \\
Emilia Romagna (other provinces) & 6 \\
Toscana & 6 \\
Veneto & 6 \\
Campania & 3 \\
Other Italian regions & 10 \\
Total & 100
\end{tabular}

Source: Our elaboration on data from Confindustria Ceramica $(2007,2008)$.

Table 2 illustrates the localisation of firms in the sample. The provinces of Reggio Emilia and Modena, both located in the Emilia Romagna region, host more than two-thirds of the companies. Veneto, Toscana and Emilia Romagna itself (excluding Reggio Emilia and Modena provinces) rank second, each accounting for $6 \%$ of the total. Campania ranks third, with a share of $3 \%$. The remaining $10 \%$ of the firms are located in other Italian regions.

The sample is largely composed of medium-sized firms with a turnover in the range of $€ 10-80$ million (43\% of the total), while the share of largest firms (with a turnover of more than $€ 80$ million) accounts for $15 \%$ of the total. Small firms represent $32 \%$ of the total.

To investigate the entry rates and performance of spin-offs in the industrial district, we closely follow the methodology outlined by Klepper (2009) for assessing the spin-off relevance and performance of some US clusters (i.e. Detroit and Silicon Valley). In detail, building on the literature presented in Section 2, we test the following hypotheses:

H1. The rate of spin-off is higher in the Sassuolo district than elsewhere.

H2. Top-performing companies generate spin-offs at higher rate than follower companies.

H3. Top-performing companies generate top-performing spin-offs.

Furthermore, to assess the role of Marshallian externalities and district-specific advantages for start-ups, which concern all potential entrepreneurs, we test the following:

H4. On average, spin-offs do not perform better than other start-ups.

\subsection{Results}

In what follows we present the main findings concerning the fertility and location of spin-offs, as well as the performance of spin-offs and other start-ups. The background of spin-offs' founders is discussed in order to shed further light on the origin and advantages of spin-offs.

4.2.1 Spin-off fertility and location. Our sample includes 87 spin-offs over the period 1953-2007. Most parent firms (89.6\%) spawned out only one child firm, six parents generated more than three spin-offs and only one of them, i.e. Marazzi, which is among the largest tile firms and is located in the Sassuolo district, had seven spin-offs. Following Klepper (2009), we compute the rate at which parents spawned out spin-offs ('birth rate') 
by dividing the total number of spin-offs by the total number of years of production. ${ }^{3}$ In Sassuolo the annual birth rate is $36 / 712=0.051$. This is twice the birth rate calculated over the other regions $(10 / 389=0.026)$. This latter finding supports the first hypothesis and is in line with the evidence about the Detroit and Silicon Valley cases.

Our data also indicate that spin-offs tend to locate in close proximity to their parents: $67 \%$ of the recorded spin-offs are located within $50 \mathrm{~km}$ of their parents and $69 \%$ are located in the same province. This latter finding indicates, similarly to the existing literature, that a significant clustering effect is driven by spin-off dynamics and that top-performing parents are a key driver of the process. Localisation choices might be affected by the origin of the founders, who are typically native of the neighbouring provinces of Reggio Emilia and Modena (Roncaccioni, 1986). However this evidence is not overruling the importance of district effects. Indeed it is very likely that spin-off founders decide to locate inside the district area in order to benefit from the presence of 'collective goods' and knowledge spillovers, as usually indicated by the industrial district literature (Russo, 1985; Solinas, 1996).

4.2.2 Spin-offs and performance. In this section we test the hypotheses that the 'quality' of parent companies reflects into number $(\mathrm{H} 2)$ and quality of spin-offs $(\mathrm{H} 3)$. It is to be noticed that we were able to collect performance data only on 54 spin-offs; therefore hypotheses H2 and H3 are tested only for this subsample. In line with Klepper (2009), we find that top-performing parents have a higher annual fertility rate as compared with low-performing parents: ${ }^{4} 26 / 404=0.064$ versus $24 / 697=0.034$. In order to test the third hypothesis, we compare the spin-offs' performance versus the parents' performance. The performance of spin-offs is measured in terms of turnover. Results indicate that only top parents generate top-performing spin-offs. In detail, 23 leading parents spawned off five top-performing spin-offs, while the low-performing parents did not contribute any top-performing spin-offs. In order to check for the robustness of this latter finding, we compute the average revenues of spin-offs from top versus non-top parents. The average revenue for the group of spin-offs from top parents is $€ 4.45$ million while that from non-top parents averages $€ 3.26$ million; the difference is statistically significant (see Table 3). Moreover, $25 \%$ of spin-offs from top parents report revenues higher than $€ 40$ million. This share decreases to $12.5 \%$ in the case of

Table 3. Performance of spin-offs (top versus non-top performers)

\begin{tabular}{llll}
\hline Parent firm & $\begin{array}{l}\text { Spin-offs' performance } \\
\text { (euro millions) }\end{array}$ & $\begin{array}{l}\text { Percentage of top- } \\
\text { performing spin-offs }\end{array}$ & $\begin{array}{l}\text { Percentage of spin-offs } \\
\text { with the highest turnover }\end{array}$ \\
\hline Top & 4.45 & $21.70 \%$ & $26.09 \%$ \\
Non-top & 3.26 & $0.00 \%$ & $12.50 \%$ \\
\hline
\end{tabular}

${ }^{a} O$ ne-tailed $t$-test of difference, significant at 0.05 level.

${ }^{b}$ Firms with a turnover of more than $€ 40$ million.

${ }^{3}$ As in Klepper (2010), we standardise our indicator by the number of years of production.

${ }^{4}$ We define leading or top-performing firms as those that had revenues above $€ 80$ million in 2002 or later years and revenues of at least 100 billion lira in either 1992 or 1997. 
spin-offs from low-performing parents.

It is also to be noticed that all top-performing spin-offs (i.e. five) are located in the Sassuolo district (i.e. provinces of Reggio Emilia and Modena) and that all of them come from a top parent also located in the district. Top-performing parents include the renowned entrepreneurial success stories of Marazzi, Iris, Florim and Atlas Concorde companies, among many others. These companies were among the pioneers in the district and greatly contributed to its growth and consolidation. These early entrants were also those that generated spin-offs, which later became themselves entrepreneurial success stories. For example, the Mussini brothers started with Concorde Ceramics in the late 1960s; in 1975, because of disagreements, they decided to split up and two of them founded a new company, Panaria, which became a large multibrand group. A few years later another member of the family founded Fiordo ceramics, which is now part of Panaria Group. Similarly, Marazzi, the biggest and perhaps most representative company in the district, contributed with several spin-offs both in the tile industry and in the related mechanical sector. For example, Giovanni Lucchese, the founder of Floor Gres (nowadays Florim), worked for several years at Marazzi before he set up his successful company in the early 1960s. Similarly, Leo Lombardi, a technician working at Marazzi since the $1940 \mathrm{~s}$, contributed with breakthrough innovations to the development of the sector (e.g. glazing scraper) and founded his own mechanical company in the 1950 s, i.e. Officina Morandi.

Overall, the above findings along with the anecdotal evidence collected through secondary sources and interviews seem to suggest that both context factors (i.e. just being there) and inherited routines may affect the success rate of spin-offs. However, in our study we cannot fully disentangle the two effects.

4.2.3 Spin-off advantages: the background of the entrepreneurs. A compelling question in the studies on the origin of the industrial districts concerns the background of the entrepreneurs. Klepper (2001, 2007, 2009, 2010) distinguishes between experienced and non-experienced firms and entrepreneurs, with spin-offs regarded as experienced. However, little attention is given to the background of founders, besides saying that they were employed in firms active in the same or related businesses. In this section we provide some further evidence on the experience of spin-offs' founders in Sassuolo, based on the district historical accounts, archives and interviews. As pointed out in Roncaccioni (1986) and further supported by our interviews, the typical profile of the founder of a spin-off is that of a middle manager, who most often deals in her day-to-day working activity with customers and suppliers. Therefore, her expertise is related to commercial and market-related contents rather than technical aspects of the production process. In our sample of spin-offs, $83 \%$ of founders match this profile, i.e. they had previous job experience as either sales managers (33\%) or executives $(50 \%)$ of a tile company. On the other hand, only $17 \%$ used to work in either a production and development or technical unit of the firm. Taking into account the characteristics of the sector can help to interpret this evidence. Similar findings have been found in earlier studies. For example, the seminal work of Prodi (1966) shows that founders of start-ups had very different backgrounds. This evidence is further confirmed by a detailed investigation of Roncaccioni (1986), who illustrates that entrepreneurs in Sassuolo had very disparate jobs before setting up their ceramic 
firms, including shopkeepers, freelancers and craftsman, along with $25 \%$ of them having previous experience in the same or related sectors.

The tile industry is a rather mature sector where innovation is mainly incremental. Therefore, strategic knowledge does not lie in those units that are dedicated to manufacturing. On the contrary, the know-who of the firm, which is socialised mostly among managers, is presumably more important than the technical know-how, as it provides access to strategic market information. Sales and senior managers are frequently updated on the latest market opportunities and get access to key information and important local resources. Indeed, they know about the requests and needs of their main clients. They are regarded as reliable and prestigious entrepreneurs among their peers and are able to mobilise social networks. In particular they establish close contacts with local institutions such as banks, local governments and trade unions. These networks of relations and contacts allow them to identify, on the one hand, emerging market niches, which may not yet be served by the parent, and, on the other hand, to mobilise resources (e.g. financial, physical and human) and support (e.g. political and institutional) to invest in new ventures. However these senior managers, who are exposed to commercial networks and gain visibility with local institutions, are more likely to be found in mid-large or 'top-performing' companies.

4.2.4 Spin-offs' and start-ups' performance. The data on performance also serve to test our fourth hypothesis: whether spin-offs perform on average better than nonspin-offs. Contrarily to what is suggested by recent literature on US clusters (see Section 2), we do not find the good performance of new firms to be strictly related to lineage from a successful parent. Rather, the evidence suggests that start-ups other than spin-offs perform better than spin-offs themselves. The average revenue in the group of spin-offs is $€ 3.75$ million, which is significantly lower than the average revenues for other start-ups ( $€ 4.83$ million) (Table 4 ). However, when controlling for the district effect, we find that spin-offs located in Sassuolo have revenues $(€ 4.39$ million) that are on average comparable with those of start-ups in the same area $(€ 4.97 \text { million })^{5}$ and significantly higher than those of spin-offs located elsewhere (€3.75 million). This latter result seems to suggest that, for the case under study, the context matters as much as or even more than inheritance. Indeed, as shown in the previous section, start-ups were founded by entrepreneurs with very disparate backgrounds. For example, this is the case of the early generation of founders in the

Table 4. Performance of start-ups by origin (district versus non-district firms)

\begin{tabular}{lll}
\hline & Turnover & Size \\
\hline Spin-offs & $3.75^{\mathrm{a}}$ & $3.00^{\mathrm{a}}$ \\
Non-spin-offs & 4.83 & 3.87 \\
District firms & $4.62^{\mathrm{a}}$ & 3.66 \\
Non-district firms & 3.39 & 3.39 \\
Spin-offs in the district & 4.39 & 3.48 \\
Non-spin-offs in the district & 4.97 & 3.89 \\
\hline
\end{tabular}

aTwo-tailed $t$-test of difference, significant at 0.05 level.

${ }_{5}$ The difference is not statistically significant. 
1960s who had no prior experience in the ceramic sector. ${ }^{6}$ Moreover, as reported in many interviews by the main players of the district, cafeteria effects were important, since they facilitated the formation of new entrepreneurial ventures. ${ }^{7}$ In other terms, for a traditional district like Sassuolo, in order to explain new firms' growth, it is important to refer to the environmental conditions, i.e. district externalities, besides individual firms' competencies or the networks the new entrepreneur acquired through experience at an established company.

\section{Conclusion}

The emergence and growth of industrial districts is often explained in terms of localisation economies coupled with supporting local institutions, cultural and historical shared roots and trustful cooperative relationships. Recently, the traditional explananda of the emergence and success of clusters have been reconsidered by a new literature on the 'cluster life cycle' (Boschma and Fornhal, 2011). In line with the seminal works by Klepper $(2001,2009,2010)$, this literature claims that spin-offs represent a key driver in the growth and performance of clusters. Spin-offs are new start-ups founded by employees of firms in the same industry, which inherit knowledge and competencies from their parent firm. Drawing on the evolutionary concept of 'heredity' (cf. Nelson and Winter, 1982), these contributions suggest that parental inheritance of spin-offs, which consists in knowledge, competencies and routines, distinguishes them from other firms in the industry. This view further implies that successful incumbents generate spin-offs at a higher rate and that their spin-offs perform on average better than other new start-ups.

In line with the above theoretical conceptualisation, we have examined the Sassuolo tile district, which is a paradigmatic example of an Italian Marshallian district. Following Klepper's analyses, we investigated spin-off dynamics and its contribution to the process of agglomeration.

Overall our findings confirm that organisational reproduction and heredity represent primary mechanisms underlying the process of clustering. In particular, in line with other evidence (e.g. Detroit and Silicon Valley), we find that the birth rate of spin-offs in Sassuolo is higher than elsewhere. Moreover, we find that spin-offs tend to locate very close to their parents, i.e. approximately two-thirds of them are within 50 $\mathrm{km}$ of their parent firms, which suggests that a significant clustering effect is driven by spin-offs dynamics. Also the 'inheritance' arguments find support in the data: better parent companies spur more spin-offs and these spin-offs exhibit a higher quality than spin-offs from lower-performing parent firms. It therefore appears that entrepreneurs who are bred in top firms 'inherit' characteristics, routines or networks that increase the likelihood their new ventures will also be a top firm. This is particularly the case for parents and their spin-offs that are located in the district, where spin-offs are most often founded by middle managers experienced with commercial functions and linked to local institutional networks.

\footnotetext{
${ }^{6}$ For example, Cirillo Mussini, which founded Concorde in 1969, was known as the The Professor because he served as Professor of Rheumatology at the University of Modena for many years until 2003. Francesco Zironi, cofounder of Ceramica Piemme, was supposed to run the family business, a wine company, but in 1962 decided otherwise. Roberto Minozzi, the founder of IRIS Ceramiche, immediately after graduation was hired by a bank but soon decided to quit and set up his ceramic company in 1961 .

${ }^{7}$ Francesco Zironi, a cofounder of Ceramica Piemme, in an interview with CerArte tells that the idea of setting a business in the ceramic industry came up while playing cards in a bar of Sassuolo, where his group of friends was used to meet up (see www.cerarte.it/pub_relazioni/rivista/rivista012/riv012_art013.htm).
} 
However our results also show that spin-offs, on average, do not perform better than non-spin-offs. On the contrary their performance tends to be below that of other companies, which apparently contradicts some of the evidence presented by Klepper and colleagues, who maintain that the success of clusters can be mainly explained by the success of the spin-offs that entered. In this respect, it appears that in dense industrial environments and social networks, competitive advantages can also be acquired or built through other channels. That is, although the evolutionary mechanism of inheritance represents a key driver of the district emergence and success, our findings do not rule out all over the 'Marshallian' explananda. Indeed some typical district features appear to have a distinct impact on the entrepreneurial dynamics. As pointed out by Klepper (2007, p. 629) for the Detroit area, it is possible that agglomeration economies were significant but only benefitted spin-offs, possibly because only they had suitable pre-entry backgrounds to benefit from the agglomeration economies.

In the case of Sassuolo it appears that being a spin-off, directly inheriting competencies, routines and relations from experienced parents, does not provide a privileged condition for taking advantage of district externalities. The district economic and social milieu provides relevant knowledge about market opportunities and access to resources that can benefit a broader group of would-be entrepreneurs. Hence, in line with established district literature, our analysis suggests that although leading firms can impact on the local system dynamics through spin-offs, the entrepreneurial process is largely influenced by context-specific factors or Marshallian externalities, such as knowledge spillovers and the supply of 'collective goods' at the territorial level.

Our analysis is not exempted from limitations. It is a single-industry and singledistrict study and therefore the findings may be specific to the ceramic industry or only to Sassuolo. However, we can claim that some of our findings, as those from most case studies on industrial districts, might be informative for other economic agglomerations. Actually, our evidence shows indeed that the dynamics of spin-offs in Sassuolo differs from other paradigmatic clusters, such as Detroit. To conclude, we believe that studies bringing additional evidence on different regions and industries would be a valuable line of future research.

Our research setting relies on a sample of firms that is not fully representative of the whole population of firms in the industry over the period under investigation. ${ }^{8}$ We can expect that the most reputable and long-lived firms are overrepresented, as these firms more easily are recorded in secondary sources or in the memory of key informants. Nevertheless, there is no strong reason to believe that the excluded firms generate a strong and systematic bias in our findings on spin-off dynamics. However, to make our conclusions more robust and to partially control for potential biases, we compared our results with additional evidence collected via interviews with local experts and from secondary sources.

\section{Bibliography}

Audretsch, D. and Feldman, M. 1996. R\&D spillovers and the geography of innovation and production, American Economic Review, vol. 86, no. 3, 630-40

Becattini, G. 1979. Dal 'settore' industriale al 'distretto' industrial: alcune considerazioni sull'unità d'indagine dell'economia industriale, Rivista di Economia e Politica Industriale, vol. 5, no. 1, 7-21

${ }^{8}$ It is worth stressing that, to the best of our knowledge, there are no sources of data on the genealogy of firms and founders for the entire population of ceramic firms in the period analysed. In addition, it can be added that most studies adopting a similar research setting suffer from the same limitation and potential bias (see Klepper, 2009; Boschma and Wenting, 2007). 
Becattini, G. 1990. The Marshallian economic district as a socio economic notion, pp. 37 51 in Pyke, F., Becattini, G. and Sengenberger, W. (eds), Industrial Districts and Inter Firms Cooperation in Italy, Geneva, International Labour Organization

Becattini, G., Bellandi, M. and De Propris, L. (eds) 2009. A Handbook of Industrial Districts, Cheltenham, Edward Elgar

Belussi, F. 1996. Policies for the development of knowledge-intensive local production systems, Cambridge Fournal of Economics, vol. 23, no. 6, 729-47

Belussi, F. and Sedita, S. R. 2009. Life cycle vs. multiple path dependency in industrial districts, European Planning Studies, vol. 17, no. 4, 505-28

Bentivogli, C. and Scillitani, L. 2002. Internazionalizzazione dei Mercati, New Economy e Sviluppo Locale: Il Distretto di Sassuolo Negli Anni '90, Bologna, Collana Centro Studi Banca d'Italia

Best, M. 2009. Massachusetts high tech: a 'manufactory of species', pp. 648-65 in Becattini, G., Bellandi, M. and De Propris, L. (eds), A Handbook of Industrial Districts, Cheltenham, Edward Elgar

Biggiero, L. and Sammarra, A. 2003. Organizational identity and identification processes: enriching theoretical tools to study industrial districts, pp. 205-32 in Belussi, F., Gottardi, G. and Rullani, E. (eds), The Net Evolution of Local Systems: Knowledge Creation, Collective Learning, and Variety of Institutional Arrangements, Amsterdam, Kluwer

Boschma, R. A. and Fornhal, D. 2011. Cluster evolution and a roadmap for future research, Regional Studies, vol. 45, no. 10, 1295-8

Boschma, R. A. and Wenting, R. 2007. The spatial evolution of the British automobile industry: does location matter? Industrial and Corporate Change, vol. 16, no. 2, 213-38

Brusco, S. 1982. The Emilian model: productive decentralization and social integration, Cambridge Fournal of Economics, vol. 6, no. 2, 235-61

Buenstorf, G. and Klepper, S. 2010. Why does entry cluster geographically? Evidence from the US tire industry, Fournal of Urban Economics, vol. 68, 103-14

Bursi, T. and Nardin, G. 2008. Il Distretto delle Piastrelle di Ceramica di Sassuolo tra Identità e Cambiamento, Milan, Franco Angeli

Camagni, R. 1991. Innovation Networks: Spatial Perspectives, London, Belhaven

Confindustria Ceramica. 2007. Piastrelle di Ceramica. Indagine Statistica sull'Industria Italiana. Anno 2006, Sassuolo, Confindustria Ceramica

Confindustria Ceramica. 2008. Piastrelle di Ceramica. Indagine Statistica sull'Industria Italiana. Anno 2007, Sassuolo, Confindustria Ceramica

Confindustria Ceramica. 2011. Indagine Statistiche sull'Industria Italiana. Anno 2010, Sassuolo, Confindustria Ceramica

Cusmano, L., Mancusi, M. L. and Morrison A. 2010. Globalization of production and innovation: how outsourcing is reshaping an advanced manufacturing area, Regional Studies, vol. 44, no. 3, 235-52

David, P. A. and Rosenbloom, J. L. 1990. Marshallian factor market externalities and the dynamics of industrial localization, Fournal of Urban Economics, vol. 28, 349-70

Dei Ottati, G. 2002. Social concentration and local development: the case of industrial districts, European Planning Studies, vol. 10, no. 4. 449-66

Garofoli, G. 1994. New firm formation and regional development: the Italian case, Regional Studies, vol. 28, no. 4, 381-93

Garofoli, G. 2002. Local development in Europe: theoretical models and international comparisons, European Urban and Regional Studies, vol. 9, 225-39

Glaeser, E. L., Kallal, H. D., Scheinkman, J. A. and Shleifer, A. 1992. Growth in cities, fournal of Political Economy, vol. 100, no. 6, 1126-52

Hilliard, R. and Jacobson, D. 2011. Cluster versus firm-specific factors in the development of dynamic capabilities in the pharmaceutical industry in Ireland: a study of responses to changes in environmental protection regulations, Regional Studies, vol. 45, no. 10, 1319-28

Iammarino, S. and McCann, P. 2006. The structure and evolution of industrial clusters: transactions, technology and knowledge spillovers, Research Policy, vol. 35, no. 7, 1018-36

Jacobs, J. 1969. The Economy of Cities, New York, Random House

Klepper, S. 1996. Entry, growth, and innovation over the product life cycle, American Economic Review, vol. 86, no. 3, 562-83

Klepper, S. 2001. Employee start up in high tech industry, Industrial and Corporate Change, vol. 10 , no. 3, 639-74 
Klepper, S. 2007. Disagreements, spinoffs, and the evolution of Detroit as the capital of the US automobile industry, Management Science, vol. 53, 616-31

Klepper, S. 2009. Silicon Valley, a chip off the old Detroit bloc, pp. 79-115 in Acs, Z., Audretsch, D. B. and Strom, R. J. (eds), Entrepreneurship, Growth, and Public Policy, Cambridge, UK, Cambridge University Press

Klepper, S. 2010. The origin and growth of industry clusters: the making of Silicon Valley and Detroit, fournal of Urban Economics, vol. 67, 15-32

Klepper, S. 2011. Nano-economics, spinoffs, and the wealth of regions, Small Business Economics, vol. $37,141-54$

Klepper, S. and Sleeper, S. 2005. Entry by spinoff, Management Science, vol. 51, no. 8, 1291-1306

Klepper, S. and Thompson, P. 2010. Disagreement and intra-industry spinoffs, International fournal of Industrial Organization, vol. 285, 526-38

Krugman, P. 1991. Increasing returns and economic geography, fournal of Political Economy, vol. 99, 483-99

Lazerson, M. and Lorenzoni, G. 1999. The firms that feed the industrial district: a return to the Italian source, Industrial and Corporate Change, vol. 8, no. 2, 235-66

Lundvall, B.-^̊. (ed.) 1992. National Systems of Innovation: Towards a Theory of Innovation and Interactive Learning, London, Pinter

Maillat, D. 1995. Territorial dynamic, innovative milieus and regional policy, Entrepreneurship and Regional Development, vol. 7, 157-65

Marshall, A. 1920. Principles of Economics, London, Macmillan

Maskell, P. and Malmberg, A. 1999. Localised learning and industrial competitiveness, Cambridge fournal of Economics, vol. 23, no. 2, 167-85

Menzel, M. P. and Fornhal, D. 2010. Cluster life cycles: dimensions and rationales of cluster evolution, Industrial and Corporate Change, vol. 19, no. 1, 205-38

Muzzioli, G., Spreafico, S. and Guaraldi, E. 2006. L'Uomo delle Ceramiche: Industrializzazione, Società, Costumi Religiosi nel Distretto Reggiano-Modenese, Archivio Osvaldo Piacentini, Milan, Franco Angeli

Nelson, R. R. and Winter, S. W. 1982. An Evolutionary Theory of Economic Change, Cambridge, MA, Harvard University Press

Paniccia, I. 1998. One, a hundred, thousands of industrial districts: organizational variety in local networks of small and medium-sized enterprises, Organizational Studies, vol. 19, no. 4, 667-99

Patton, D. and Kenny, M. 2009. The university research-centric district in the United States, pp. 549-64 in Becattini, G., Bellandi, M. and De Propris, L. (eds), A Handbook of Industrial Districts, Cheltenham, Edward Elgar

Piore, M. and Sabel, C. 1984. The Second Industrial Divide: Possibilities for Prosperity, New York, Basic Books

Prodi, R. 1966. Modello di Sviluppo di un Settore in Rapida Crescita, Milan, Franco Angeli

Rabellotti, R., Carabelli, A. and Hirsch, G. 2009. Italian industrial districts on the move: where are they going? European Planning Studies, vol. 17, no. 1, 19-41

Roncaccioni, A. 1986. Un'Analisi Empirica dell'Imprenditorialità, Padova, CEDAM

Rullani, E. 1997. L'evoluzione dei distretti industriali: un percorso tra decostruzione e internazionalizzazione, pp. 54-85 in Varaldo, R. and Ferrucci, L. (eds), Il distretto industriale tra logiche di impresa e logiche di sistema, Milan, Franco Angeli

Russo, M. 1985. Technical change and the industrial district: the role of interfirm relations in the growth and transformation of ceramic tile production in Italy, Research Policy, vol. 14, no. 6, 329-43

Russo, M. 1996. Cambiamento tecnico e relazioni tra imprese, Turin, Rosenberg \& Sellier

Russo, M. 2004. Processi di innovazione nei distretti e globalizzazione: il caso di Sassuolo, Economia e Società Regionale: Oltre Il Ponte, vol. 3, 5-34

Scott, A. J. 1988. Flexible production systems and regional development: the rise of new industrial spaces in North America and Western Europe, International fournal of Urban and Regional Research, vol. 12, 171-86

Serri, A. 2008. Roma-Sassuolo: Biglietto di Sola Andata-Piccola Storia dell'Industria Italiana delle Piastrelle, Modena, Arbe Editore

Solinas, G. 1996. I Processi di Formazione, la Crescita e la Sopravvivenza delle Piccole Imprese, Milan, Franco Angeli 
van der Panne, G. and van Beers, C. 2006. On the Marshall-Jacobs controversy: it takes two to tango, Industrial and Corporate Change, vol. 15, no. 5, 877-90

Vertova, G. 2004. Industrial districts in Italy: the case of Sassuolo, pp. 32-41 in Harris, P. and McDonald, F. (eds), European Business and Marketing, London, Sage

von Hippel, E. 1987. Cooperation between rivals: informal know-how trading, Research Policy, vol. 16, 291-302 